\title{
CrimRxiv
}

\section{Actualising the right to adequate standard of living: A critical examination of green criminology from an Indian perspective}

Srinivasan Murugesan ${ }^{1}$, Shankar Prakash Alagesan ${ }^{1}$

${ }^{1}$ Department of Criminology, University of Madras

Published on: Jul 05, 2021

DOI: $10.21428 / c b 6 a b 371.6 b b b 5746$

License: Creative Commons Attribution 4.0 International License (CC-BY 4.0). 


\begin{abstract}
During the last 70 years, several international instruments have been emphasising the importance of the right to adequate standard of living (Article 25, Universal Declaration of Human Rights (UDHR)) and to make cities and human settlements inclusive, safe, resilient and sustainable (Sustainable Development Goal (SDG) 11). However, many of the provisions of such international instruments, particularly the right to adequate standard of living, is too far from becoming a reality. The authors of this chapter have substantiated their arguments by presenting a few case studies conducted in the city of Chennai (formerly Madras, India). The disjuncture between the provisions of the international instruments and the reality of the contemporary quality of the environment is also to some extent exposed in this paper. It is also argued why the scope of green criminology should be widened to study the various forms of environmental crime, environmental harm and connected issues. The authors strongly believe that understanding such issues from the perspective of green criminology would provide several benefits, including sensitising the stakeholders.
\end{abstract}

Keywords: UDHR, SDG, green criminology, environmental crime, environmental harm, standard of living, human settlement, municipal solid waste, waste management.

\title{
1 Introduction
}

Right to adequate standard of living is directly connected with the quality of the environment in which an individual lives. Over a period of 70 years, a host of international instruments including the UDHR and United Nations SDGs have been emphasising the importance of protecting the right to adequate standard of living and make the cities and human settlements, inclusive, safe, resilient and sustainable.

Despite these international initiatives, the right to adequate standard of living could not be actualised by a vast section of the population, particularly in countries like India. People in India encounter a host of environmental issues which undermine their quality of life, particularly the standard of living of the disadvantaged sections of the society (Chandra 2015).

Criminologists and criminal justice practitioners have a responsibility to scientifically study a variety of environmental problems, which will expand the scope of criminology in general and green criminology in particular. Such endeavours would certainly contribute to protecting the environment and the various species that thrive in the 
environmental ecological system. There are several unexplored, untapped and untouched issues to which green criminology can be applied - by redirecting emphasis to omitted forms of environmental harms and methods to control those harms to improve the environmental quality, which can contribute significantly to both criminology and green criminology. For example, how the green approach can integrate environmental policy and crime control policy is demonstrated by examining the eco-city perspective and its design principles (Lynch 2012). Further, the existing criminological research by and large has not paid attention to various environmental issues, crimes against the environment, victims of environmental crime and various laws and the mechanisms to prevent and detect these offences (Lynch et al. 2015; Nurse 2017; Hall 2014; White 2003). Given this background, the authors of the present paper have attempted to explain certain environmental problems and argue how explaining those environmental problems from the perspective of green criminology would provide an understanding of the problem holistically and sensitise the stakeholders. The authors of this chapter argue the need for and significance of widening the scope of green criminology, particularly in the Indian context, to address various environmental issues including solid waste management. Green criminology would thus help empirically analyse the issues and generate evidence-based literature. Further, the authors argue that the right to adequate standard of living (as mandated by Article 25 of the Universal Declaration of Human Rights and Sustainable Development Goal 11) could be actualised through the efforts of policymakers as well as the local administration. The literature generated through empirical studies would be essential in this respect.

\section{The Universal Declaration of Human Rights}

The UDHR was adopted by United Nations General Assembly in 1948 (GA/RES/217A (III)). This document still remains relevant in the contemporary world. That this declaration has been translated into more than 500 languages speaks of its significance in the current scenario (United Nations). All the member states have committed to implement the provisions of the declaration. Broadly, the UDHR promises to all the human beings a life that ensures their economic, social, political, cultural and civic rights and that is free from fear and bond. These rights are universal in nature and timeless, and do not just apply to a country, or a particular social group or a particular period. The rights promised in the declaration are the inalienable rights of all people at all times and in all places (Al Hussein 2015). The preamble of the UDHR has also clearly spelt out that the recognition of the inherent dignity and the equal and inalienable rights of every member of the human family is a basis of freedom, justice 
and peace in the world. Article 1 of the UDHR states that all human beings are born free and are equal in dignity and rights. Also, all human beings have an inherent quality to reason and are endowed with conscience. Therefore, the article clearly stipulates that all human beings should act towards one another in a spirit of brotherhood. According to Article 25(1) of the declaration, all human beings have the right to have a standard of living adequate for their health and their family members. The right to adequate standard of living includes access to food, clothing, housing and medical care and the required social services. Everyone has the right to security in the event of unemployment, during sickness, if they are disabled, in the event of their widowhood, in old age or any other lack of livelihood in circumstances beyond their control (United Nations 2015).

All the member states therefore should take steps to ensure that all her citizens enjoy an adequate standard of living. However, it would be difficult to define "adequate standard of living" because different member states have different economic and social histories and capacities and also varied understanding of what is meant by adequate standard of living (Almeida et al. 2003). Some international instruments have also emphasised the importance of standard of living but in a different language. According to Article 12(1) of the International Covenant on Economic, Social and Cultural Rights (ICESCR), the state parties should recognise the right of everyone to enjoy the highest attainable standard of both physical and mental health (GA/RES/2200A (XXI)).

This covenant has also recommended certain steps to be taken by the states to achieve the full realisation of the right to the enjoyment of higher attainable standard of physical and mental health. Article 12(2) states that steps should also aim at the improvement of all aspects of environmental and industrial hygiene (GA/RES/2200A (XXI)).

\subsection{The UDHR vis-à-vis Environmental Protection}

Though the UDHR does not explicitly mention about the protection of environment, it indirectly indicates that adequate standard of living can be ensured through providing proper environment, which was not a major concern when the UDHR was adopted. It should also be noted that the attention of the international community with regard to the need for appropriate management and protection of the environment gained momentum in the 1960s. Only in the early 1970s, the environmental concepts were crystallised, particularly at the United Nations Conference on the Human Environment (UNCHE) held at Stockholm in 1972. This conference considered the need for both common approach and for common principles to inspire and guide the people of the 
world in the preservation and improvement of the environment. At the end of the conference, a declaration, popularly called the Stockholm declaration, was adopted by the participating nations (A/CONF.48/14/Rev.1). According to the declaration, most of the environmental problems in developing countries are caused by under-development. Millions of people continue to live far below the minimum levels needed for a decent human existence. They are deprived of adequate food, clothing, shelter, education, health and sanitation. The declaration, therefore, called on developing countries to direct their efforts to development, keeping in mind their priorities and the need to preserve and enhance the environment.

Particularly, principle 1 of the Stockholm declaration recognises the right to a healthy environment. This principle has also expressed the link between human rights and the environment since it declared that man has the fundamental right to freedom, equality and adequate conditions of life of dignity and well-being. It also declares that man bears a sincere responsibility to both protect and improve the environment for the present as well as future generations. The above principle also has introduced another dimension, namely, inter-generational equity. Following the Stockholm declaration, there have been several international initiatives such as the Hague Declaration on the Environment (1989), the United Nations General Assembly Resolution 45/94 (14 December 1990), the Rio Declaration on Environment and Development (1992), the Experts Group of the World Commission on Environment and Development (1996) and so on (A/CONF.48/14/Rev.1; Emeseh, 2012).

Apart from the initiatives listed before, the right to a clean and healthy environment is emerging as a part of international law. Though this rights perspective is an emerging component, its origin can be traced to the 1970s. A non-profit public interest law firm called Earth Justice was founded in 1971, which is dedicated to protecting the natural resources, the wildlife of the earth and also to defend the right of all citizens on the earth to a healthy environment. This organisation has consultative status with United Nations Economic and Social Council (O'Gara et al. 2007). In May 1994, an international group of experts on human rights and environmental protection drafted the Declaration of Principles on Human Rights and the Environment (Ksentini Report). The Draft Declaration, considered as the first international instrument, comprehensively addressed the link between human rights and the environment. The Draft Declaration also demonstrates that the accepted environmental and human rights principles illustrate the right of everyone to secure a healthy and ecologically sound environment. It further describes the environmental dimensions of established human rights including the right to life, the right to health and the right to culture. The 
procedural rights (the right to participation) necessary for the realisation of substantial rights are also mentioned in the declaration. The corresponding duties apply to individuals, governments, international organisations and transnational corporations to respect this right (E/CN.4/Sub.2/1994/9). In September 2007, the United Nations General Assembly adopted the United Nations Declaration on the Rights of the Indigenous Peoples, which recognised the urgent need to respect and promote the inherent rights of indigenous peoples which derive from both political and socio-economic structures and also from their cultures, spiritual traditions, histories and philosophies, particularly their rights to their lands, territories and resources (A/RES/61/295). The various United Nations organs and agencies, including the United Nations Economic and Social Council (ECOSOC), United Nations Human Rights Council (formerly UN Commission on Human Rights (UNCHR)) and UN Environment Programme (UNEP), have not only established the link between environmental protection and human rights but also recognised the human right to a clean and healthy environment. Unfortunately, all international instruments mentioned earlier are considered as soft laws since they don't possess a binding legal force. However, such laws can be hardened if adopted in practice by the states and thus over time transform into norms of customary international law, in which case they would be binding and legally enforceable. Several regional human rights instruments (for example, African Charter on Human and Peoples' Rights) have recognised the right to a healthy environment. Some state constitutions in the United States (e.g. the Constitution of Montana) also provides for such rights (Emeseh 2012). In this context, it is also worthwhile to mention the Aarhus Convention (United Nations Economic Commission for Europe 1998). This relates to the United Nations Economic Commission of Europe (UNEC) Convention on Access to Information, Public Participation in Decision-Making and Access to Justice in Environmental Matters, which was adopted at the Fourth Ministerial Conference as part of the 'Environment for Europe' process in June 1998 in the city of Aarhus (Denmark). The procedural aspect of the right to healthy environment, articulated in principle 10 of the Rio Declaration is also enshrined in the Aarhus Convention. The Convention has established a number of rights for the public with regard to the environment. The World Development Report published by the World Bank in 2006 has also recognised the importance of procedural rights spelt out in the Aarhus Convention (Emeseh 2012).

\section{Agenda for Sustainable Development and the Right to Adequate Standard of Living}


In September 2015, the United Nations General Assembly in its 70th session adopted the 2030 Agenda for sustainable development. As spelt out in the preamble of the agenda, it is not only a plan of action for people, planet and prosperity but also seeks to strengthen universal peace and larger freedom. There are 17 SDGs and 169 targets announced in the agenda. All the 17 SDGs and 169 targets seek to build on the Millennium Development Goals. They also seek to realise the human rights of all and to achieve gender equality and empowerment of all women and girls. All the goals and targets are integrated and indivisible and also balance the three dimensions of sustainable development, namely, the economic, the social and the environmental. The 2030 Agenda is guided by various international instruments. The principles of the charter of the United Nations has guided the agenda. It is also grounded in the international human rights treaties, including the Universal Declaration of Human Rights, the Millennium Declaration and the 2005 World Summit outcome. The 2030 Agenda is further informed by other international instruments such as Declaration on the Right to Development. The outcomes of all the major United Nations conferences and summits not only laid a strong foundation for sustainable development but also shaped the new agenda. Some of the conferences and summits which have direct relevance to sustainable development includes Rio Declaration on Environment and Development, the World Summit on Sustainable Development and the United Nations Conference on Sustainable Development. These conferences and summits have identified both the challenges and commitments which are interrelated and requires integrated solutions. In order to address these challenges and commitments, a new approach is needed. Sustainable development recognises that eradicating poverty, combatting inequality, preserving the planet and creating a sustained, inclusive and sustainable economic growth are linked to one another and are also interdependent. One of the goals of the SDG (SDG 11) is to make cities and human settlements inclusive, safe, resilient and sustainable. According to SDG 11, by 2030 all the countries and all stakeholders will take efforts to enhance 'inclusive and sustainable urbanisation and capacity for participatory, integrated and sustainable human settlement planning and management in all countries'. The goal also is set to 'reduce per capita environmental impact of cities including by paying attention to quality of air and municipal and other waste management' (A/RES/70/1). While this is the goal set to be achieved by 2030, the findings of the Sustainable Development Goals Report 2019 provided shocking data. Based on the data collected between 2010 and 2018, it was found that two billion people were without waste collection services and three billion people did not have access to controlled waste disposal facilities. In 2016, the total amount of waste generated globally was two billion metric tons and is expected to 
double (to about four billion metric tons) by 2050. Between 2001 and 2010, the proportion of municipal solid waste collected regularly was $76 \%$, which increased to $81 \%$ between 2010 and 2018. The report has also revealed that in low- and middleincome countries, many municipal solid waste disposal facilities are open dumping sites. This improper form of solid waste disposal contributes significantly to air, water and soil pollution. The report went on to suggest that investment in waste management infrastructure is urgently needed to improve the solid waste management across most of the countries in the world (United Nations 2019). This disconnect between the goal set in the 2030 agenda and reality in the contemporary world is a matter of serious concern. This should become the subject matter of criminology in general and green criminology in particular. Some authors have discussed at length why criminologists should contribute to the 2030 agenda and how the knowledge of criminologists and their experience would benefit the international development community (Blaustein et al. 2018). The role of criminologists also assumes significance since the SDGs address issues relating to crime, justice and security. For instance, Blaustein et al. (2018) suggest that the criminologists can support the 2030 agenda mainly in two ways. One way is that criminologists can assist with the design, implementation, evaluation of projects which would support safe, just and environmentally sustainable societies. This does not mean that criminological knowledge alone is sufficient for bringing about these outcomes. It should be combined with the expertise of development actors and aligned with stakeholder interest and knowledge.

The second way is that criminologists can assume a critical role by lending their expertise to the members of development community and local stakeholders. Specifically, criminologists with expertise on environmental crime can significantly contribute to the 2030 agenda since environmental sustainability lies at the heart of the SDGs. Blaustein et al. (2018) have also highlighted how criminologists can contribute to the realisation of various SDGs including SDG 11.7. This particular goal aims to provide universal access to safe, inclusive and accessible, green and public spaces particularly for women and children, persons with disabilities and older person.

\section{Municipal Solid Waste Management in Chennai}

Municipal solid waste management (MSWM) is a critical task in metropolitan cities. MSWM is the responsibility of urban local bodies, which in metropolitan cities in India are called corporations. MSWM comprises segregation, collection, storage, transportation, processing and disposal of solid waste to reduce its unfavourable 
impact on the environment. Poorly managed municipal solid waste (MSW) is one of the causes of innumerable urban disorders (Kumar et al. 2009).

MSWM is governed by Solid Waste Management Rules, 2016 under the Environment (Protection) Act, 1986. However, majority of urban local bodies do not have pertinent action plans for the execution and enactment of MSWM. It is unfortunate that no city in India can claim 100\% segregation of MSW. The waste produced in India consists of approximately 40-60\% compostable, 30-50\% inert and 10-30\% recyclable. Out of the total waste collected, only $12.45 \%$ is scientifically managed and the rest is disposed in open dumping grounds (Central Pollution Control Board 2013; Joshi and Ahmed 2016). There is also no organised and scientifically managed segregation of MSW either at the household or community level. Waste producers are seldom involved in the process of segregation. This lack of segregation at source means scientific disposal of waste does not happen (Kaushal et al. 2012; Singhal and Pandey 2001). Waste produced by households and street sweepings are usually transferred into community bins. Some commercial complexes and industrial units engage local bodies for the transfer of their waste to open dumping grounds. Uncontrolled open dumping is a common scenario in almost all cities (Kumar et al. 2009; Pujara et al. 2019). Dumping grounds and landfilling would continue to be a widely accepted practice in India. Metropolitan cities like Delhi, Chennai, Kolkata and Mumbai have limited availability of land for dumping grounds, which often exceed their carrying capacity (Sharholy et al. 2008).

In this background, a case study was conducted in Chennai, the capital city of the southern Indian state of Tamil Nadu. According to Indian Census 2011, the city had 4.54 million residents, living in 1.15 million households. The present estimated population of Chennai is about 8.9 million, making it the fourth most populous city in India. The Greater Chennai Corporation (GCC) is responsible for managing solid waste produced in the city. The jurisdiction of the city was extended in 2011 by increasing its area from 174 square kilometres to 426 square kilometres. Now the jurisdiction of GCC covers three revenue districts, namely, Chennai, part of Kanchipuram and part of Thiruvallur. On a daily basis, around 5400 metric tons of MSW is collected from the city. The city generates wastes in the following categories: (a) residential (68\%); (b) commercial (16\%); (c) halls, schools and institutions (14\%); (d) industrial (2\%) and hospitals and clinics (separately disposed by hospitals/clinics by the supervision of Tamil Nadu Pollution Control Board). At present, MSW generated in Chennai city is dumped at two dumping grounds: Kodungaiyur Dumping Ground (KDG) and Perungudi Dumping Ground (PDG) (Greater Chennai Corporation; Greater Chennai Corporation 2017; National Informatics Centre; Office of the Registrar General \& Census 
Commissioner). KDG is located in the northern part of Chennai and has been in operation since 1980, now extending to about 5 square kilometres. At the time of its inception, households were already present at the site. Now people are living within a 500-metre distance from the KDG, whereas PDG began its operation from the southern part of Chennai in 1987. During that time, there were no households in its vicinity. But due to rapid expansion of the Chennai city, now the households are within a 500-metre distance from PDG (Greater Chennai Corporation; Parameswari and Mudgal 2014; Eshanthini and Padmini 2015; Ammasi Krishnan et al. 2019).

\subsection{Case 1: Kodungaiyur Dumping Ground}

The local community informs that till the 1960s, the KDG site was a marshy wetland dominated by grasses, which served as a fodder farm for cattle. Initially there were around 15 huts. As it was a marshy wetland, people used to fill the land with the wastes generated from the Kothavalchavadi Market. Filling the land with construction and demolition waste was costlier compared to market wastes. Hence, the residents who occupied the lands used the site to discard wastes generated from Kothavalchavadi. In the early 1980s, municipal waste from the Chennai city started to be dumped here, which continues even today. The dumping ground receives all types of waste from MSW to hazardous industrial wastes to medical wastes. There are around 100 recyclers (80 of them are women) who depend on this dump yard for their livelihood. They will collect polyethylene (PET) bottles, glass bottles, surgical gloves, rubber slippers, cardboards, metals etc. Since the government failed to segregate wastes at source, the recyclers segregate the waste in the dumping ground. As the dumping ground receives medical waste and some hazardous chemicals, frequently they are inundated with syringes, surgical equipment and exposure to toxic chemicals.

During the rainy season, an unbearable stench emanates from the dump site. Regarding health conditions, the residents around the site are afflicted with a skin infection due to groundwater contamination. The residents are vulnerable to respiratory and skeletal disorders. Previously solid wastes from lorries used to be discarded during daytime and hence the foul smell wouldn't be felt as much. But nowadays, the wastes are dumped in during the night with continuous trips of lorries with the wastes stocked for two or three days in various collection centres. So the stench from the waste has become unbearable. Further, feral dogs cause nuisance at the dumps.

\subsection{Case 2: Perungudi Dumping Ground}


The community members say that around 1987 or 1988, the present Perungudi site was chosen by the Chennai Corporation for dumping MSW. Perungudi dumping ground lies on the Pallikaranai marshland. And around 35\% of the marshland is occupied by the dumping ground and it is still expanding beyond its carrying capacity. The residential areas such as Vinayaga Nagar, Sai Nagar and Sri Kumaran Nagar are very close to the dumping ground. Some years back, in order to increase the longevity of the dumping ground, there was a continuous burning of garbage. It had a negative impact on people residing close-by as it caused various respiratory problems such as chronic cough and asthma.

Ground water in the locality is contaminated because of the dumping ground. As the dumping ground is also a breeding place for mosquitoes, diseases like malaria and dengue are common among the residents. House flies are also a major problem in the neighbourhood, as it is responsible for spreading a range of diseases and infections like cholera, conjunctivitis, dysentery and gastroenteritis. Though the GCC is insisting on segregation of waste at source, the people and conservancy workers are not following it anymore. The GCC has been making announcements regarding plans for a scientific remediation of the dump yard for the past eight years. But so far, none of those plans have been executed.

A recycler aged 37 years from the PDG narrated that

Usually the day for me starts at six in the morning and lasts up to seven in the evening. I am very proud that as I could contribute to the waste management by segregating recyclable items from the municipal solid wastes. Collecting recyclable items such as plastic, cardboard, glass bottles etc. is the only source income for our sustenance. We will sell those collected items to the scrap merchants. A daily segregation of the waste may range from 5 kilograms to 30 kilograms. I am into this work by knowing it will definitely cause health risks. As I am handling garbage without any protective gears, I am very susceptible to develop worms, anaemia, respiratory problems etc. Moreover, very often, while segregating waste I am exposed to maggots. It causes a discomfort while having food. As the dumping ground receives all the types of wastes, very often injuries will occur due to cuts and falls. The presence of feral dogs sometimes gives rise to the threat of bites. Very often municipal waste contains disposable syringes and most of the recyclers are afraid of it may cause AIDS if we are injured with such syringes. Apart from the above said health hazards, most of the recyclers are 
affected with skin diseases. If anything happens, I need to visit the nearby government hospital as costs at private hospitals are higher.

It is therefore clear that improper MSWM can have negative impacts on both environment and public health. Lack of scientifically sound handling and disposal activity could result in soil, water and air pollution. Any deficiency in waste disposal or dumping untreated waste may cause serious health problems for populations surrounding the area of dumping grounds. Leaks from the dumped waste may contaminate soil, ground water and water streams. The presence of heavy metals and persistent organic pollutants will produce air pollution, which ultimately creates health hazards (World Health Organization 2016). In line with World Health Organization (2016) several literature suggest that a direct landfill disposal (without any pretreatment) of MSW causes considerable geo-environmental problems such as emission of greenhouse gases (GHGs), hazardous volatile organic compounds, groundwater contamination due to seepage and leaching and noxious odours. With regard to human health, studies employing geographic or spatial approaches have suggested that there is an association between household proximity to dumping grounds and health-related effects (Gouveia and do Prado 2010; Fernández-Nava et al. 2014; Patil et al. 2017). Shaddick et al. (2018) opined that higher risk of low birth weight, congenital anomalies (inherited medical condition that occurs at or before birth), respiratory diseases and annoyance from stench were reported among people who live closer to such dumps. Some studies (Bergersen and Haarstad 2014; Lillycrop et al. 2015) showed a significant association between hydrogen sulphide (major odorant at municipal landfills) exposure and deaths caused by lung cancer. Symptoms of respiratory diseases are visible in people who reside near the dumping grounds. The residents were exposed to endotoxin, aerosols and microorganisms from the dumping grounds. Apart from the physical health problems, there is evidence for psychological and emotional impact among the residents living close to dump sites. In several instances, solid waste has been reported to contain human body parts and aborted foetuses, which may affect mental well-being of the residents who stay closer to dump sites. Scavenging animals and birds may also create nuisance to the people (Vrijheid 2000; Brinkel et al. 2009; Ziraba et al. 2016).

Specifically with regard to the health impact of residents near KDG, Deivanayagam et al. (2007) identified that air pollution from the dump critically affected the residents and significantly children. Many of the children reported to have perennial cough and cold, skin diseases, growth retardation, fevers and few other chronic ailments. This results in high absenteeism among school going children. Apart from the above, the 
residents are exposed to carcinogens such as acrylonitrile, 1,4-dichlorobenzene and chloromethane. Eventually, it will show up as cancerous growth in skin, lungs, throats, urinary bladder and any of the internal organs. Although one of the findings of the study (Deivanayagam et al. 2007) indicate that a serious health problem affects the school attendance rate of children, the research has not examined high absenteeism (truancy) as an indication of deviant behaviour. In other words, if the same study was carried out from a green criminological point of view, it would have brought to light a few other criminological issues, including deviance among children.

As it is obvious from what is happening to people living near dump sites, what is clear is that it is impossible to enjoy one's life without the protection and preservation of the environment. Also, an equilibrium between living organisms free from pollution of air, water, soil and sanitation will ensure one's healthy being. Hence, environmental degradation or ecological abuse is considered to be serious than any type of physical abuse of humans. Environmental degradation and ecological abuse that is statesponsored are often connected with inequitable distribution of environmental hazards (Adeola 2001). In India, most of the dumping grounds are managed by respective state's civic bodies. The management of solid waste and dumping grounds is the primary responsibility of civic bodies. There are specific provisions given in the Solid Waste Management Rules, 2016, under the Environment (Protection) Act, 1986, to manage solid waste, and whoever fails to comply with or contravenes any of the provisions of this Act will be prosecuted. This may be considered as a preventive strategy. Besides, civic bodies occasionally create awareness among the general public on the appropriate methods of solid waste segregation. Although it is an element that prevents people from not violating the provisions of Environment (Protection) Act, 1986 , it cannot per se be called as crime prevention by the civic bodies. There is a wide network of Non-Governmental Organisations (NGOs) involved in environmental protection including aiding in creating awareness among people in protecting their environment. However, all the efforts have not culminated in the form of movement for green spaces or safe environment.

The above description of the hard reality demands the attention of academics, administrators, policy-makers and also those who are concerned with environmental sustainability to focus on the ways and methods of addressing or improving MSWM in order to realise SDG 11. Currently the situation is very grim because of the impact of the improper solid waste management on the people in general and on the marginalised communities in particular, on whom it is greater. This cannot be approached simply as an administrative or management issue but rather it should be 
addressed through a multi-disciplinary approach. The role of criminologists in general and green criminologists in particular would also be greatly required to address a more complex issue such the impact of improper MSWM on the people.

\section{Understanding Green Criminology}

The term 'green criminology' was introduced in the criminological literature by Lynch (1990). He is currently a professor in the Department of Criminology and an associate faculty member in the Patel College of Global Sustainability, University of South Florida, USA. In the 1990s, some authors (for example South 1998) used the term green issues to include the environment, animal rights and the relationship between human societies and ecological systems. South (1998), in his article, focused on the natural environment and its relationship with criminological concerns. In the field of criminology, such a relationship was considered as underdeveloped and hence the term 'environmental' was still chiefly employed in studies of place and spatial patterning of crime (Bottoms as cited in South 1998). Given this status, South (1998) advocated the enhancement of environmental consciousness in the field of criminology and also for the development of a green perspective. Though he emphasises the importance of "thinking green" as a sensitising perspective, he did not put forward a 'theory' for or of 'a green criminology'. He argued further that such a sensitising perspective should find a prominent place in the criminological agenda. He further expressed his intention explicitly that a green perspective could be reasonably placed alongside other source of change and critique in fields such as feminism, postmodernism, minority representation etc. Some authors have criticised the field of criminology as a fragmented discipline. For example, Ericson and Carriere, as cited in South (1998), observed that criminology is a fragmented field of enquiry and a part of broader process of fragmentation in the academy, and in other social institutions and also in the risk society. Ulrich Beck and Anthony Giddens initially developed the risk society hypothesis, which gained acceptance in the field of sociology and created a debate about risk in postmodern society (Etkin 2016). Due to this fragmented nature of criminology, particularly in the study of the environmental issues of risk society, a green perspective is suggested.

Several other authors over a period of time have attempted to define green criminology. In the late 1990s, some authors engaged in defining the term green. Groombridge (1998) was of the opinion that it is not simply possible to adopt a "green" approach without bringing with it the other issues such as theoretical and methodological. During the same period, South (1998) stated that it would be valuable 
to describe what the green criminological theories may look like. Therefore, it is necessary to define the meaning of the term green in the process of designing a green criminology. According to Lynch and Stretesky (2003), defining green criminology requires embracing an array of various conceptions and not simply on what green criminology is, but also on conceptions such as what does green criminology seek to achieve; what approach should or should not be included; and contradictory perspectives on what it means to be green.

Lynch and Stretsky (2003) took the view that like other crimes, green crimes are also social constructions influenced by both social locations and power relations in the society. With regard to power issues, they wanted to examine the meaning of the term green since they considered that the meaning of the term green is influenced by two distinct groups, namely, corporate activists and environmental justice activists/movements. That is, they wanted to sketch the main issues connecting points required to construct a definition of green criminology that would recognise the influence of corporate power structures and also the achievements of environmental justice activists/movements.

Green criminology is described as a research area focusing on environmental crime, environmental harm, environmental laws, environmental justice, environmental regulation, victimisation due to environmental crime and so on. The subject matter of green criminology also included moral and philosophical issues relating to environment as such issues relate to human beings, animals, plants and ecosystems and its components (White 2008).

While tracing the origin and evolution of green criminology, White (2013) commented that though there have been a number of scholars working on issues relating to environmental crime, they were not necessarily exploring the green criminology perspective. The author made a reference to various bodies of work on environmental issues that are informed by literature on corporate and organised crime. For example, environmental harm and crime are linked to both the activities of corporations and to organised criminal syndicates. The above issues are not analysed through a green criminology perspective but through the lens of sociology of deviance and political economy. The focus of such studies were on the control and manipulation of waste disposal processes and protection and distribution of toxic chemicals and so on (Ruggiero 1996; Massari and Monzini 2004; Pearce and Tombs 2019).

Few other authors have specifically looked at environmental crime but within the conventional framework. The focus of such analysis has been on traditional illegal 
activities linked with the environment such as illegal fishing etc. However, such an analysis has been done within the traditional criminological approaches. Broadly the focus of the works of such authors has been based upon the legal concepts of environmental crime, existing legislations and the regulations relating to environmental crime, the nature of environmental law enforcement agencies etc. (Situ and Emmons 2000; O'Connor Shelley and Crow 2009; Fyfe and Reeves 2010). The above criminological works, to some extent, overlap with the traditional legal studies (violation of criminal law and civil statutes) in the area of environmental crime. The key concepts and concerns of these studies lie in the area of substantive law including concepts such as vicarious liability, public interest etc. These studies have also attempted to place a legal or monetary value of environmental harm (Brickey 2008; Mehta 2009; Bell et al. 2017).

Another group of studies has also applied sociological analysis to questions pertaining to environmental justice. The main focus of such studies was to explore the empirical links between toxic environments and some categories of people such as the poor and the dispossessed and also to wage a struggle against issues such as discrimination and racism that underpin such ecological injustice. The issues such as distribution of environmental advantage and disadvantage instead of crime per se are the key concepts and concerns emphasised by the above group of studies (Bullard 2005; Pellow 2007).

In the 1990s when the sub-discipline of green criminology emerged, the writings were about the need for criminology to take environmental crimes seriously and to do so in ways that would force the discipline criminology to rethink on the question such as how it does, what it does and also how to conceptualise the issue. The idea of green criminology itself was one of the key concepts and concerns that was the subject matter of analysis during the early period. The other concepts and concerns included the idea that green criminology is not a theory but only a perspective and also the social and ecological significance of studying environmental crime and harm (Lynch 1990; Clifford 1998; South 1998). During the current decade, broadly the term green criminology is used to refer to the study by criminologists of environmental harms, environmental laws and environmental regulation.

In 2014, Lynch and Stretesky in their book titled Exploring Green Criminology: Towards a Green Criminological Revolution have dealt in detail both the definition and scope of green criminology. According to them, green criminology is a means for studying various problems relating to environmental harm and crime, environmental 
law, environmental regulation, environmental justice and victimisation due to environmental crime, moral/philosophical issues since such issues are relating to humans, non-human animals, plant species and so on. The subject matter of green criminology also includes the study of ecosystems and its components. The authors have also attempted to build a green criminological typology by examining the types of research recognised as falling under the green sciences. For a long time, natural scientists have taken up environmental issues and their attention to green studies precedes the emergence of green criminology. Therefore, the concepts employed by natural scientists to organise their green research initiatives are useful for developing a seminal approach within green criminology. One of the reasons for taking this approach to developing a green criminological typology is that the orientation can be adopted to demonstrate inter-connections and intersections between green criminology and green science.

The advantage of focusing on the overlap between green criminology and green science is to encourage green criminologists to draw on the related scientific literature to support their views and ideas. Further, these authors are of the view that green criminology cannot make a substantial contribution to the study of crime and justice without making its connection to science. To demonstrate such a connection and make them more obvious, these authors reviewed the overlap between green criminology and green science in three primary areas: (a) eco approaches: research that addresses environmental issues in relation to non-human species and also their intersections with natural ecology; (b) enviro approaches: research that addresses issues relating to pollution that will have impact on human species and their interaction with environment; (c) green policy approach: research that addresses solutions to environmental harms and their prevention.

However, the above three approaches do not exhaust all types of green criminological research. Still there is a significant quantum of research not covered by these three primary areas of intersections. That is there are various issues addressed by the green criminologists but not included within the green natural science approaches. Green contextual approach is a unique green criminological contribution that stems from research connecting environmental issues to various theories including economic, social, political and philosophical theories (Lynch and Stretesky 2014).

\section{Green Criminology: A tool to implement SDG 11}

As discussed above, the right to adequate standard of living for an individual is directly related to the quality of the environment. Article 25(1) of the UDHR and SDG 11 
provide for adequate standard of living and detail ways to make human settlements inclusive, safe, resilient, and sustainable. In order to achieve these ideals, there is a need to strengthen the MSWM capabilities of various countries. The authors of this chapter strongly believe that the nature and scope of green criminology has to be expanded so as to provide a holistic approach to the study of environmental problems and various environmental issues, including MSWM. In this direction, earnest effort has been made by the authors in the form of a case study conducted in the city of Chennai, which can serve as a prelude for future studies from a green criminological perspective.

Globally, the scope of green criminology has been expanding, through both research and practice. However, in Indian context, literature in the field of green criminology is sparse. While acknowledging the fact that various problems relating to environmental harm, environmental law, environmental regulation and so on are studied independently, a comprehensive approach to environmental sustainability is not a common approach in India. For instance, the improper MSWM is not an issue to be studied from a management perspective but from the perspective of criminologists and victimologists. Independent researchers and governmental agencies have estimated that nearly $80 \%$ of MSW is disposed in open dumping grounds. The impact of improper solid waste has also been studied extensively. The health hazards of the people living closer to open dumping grounds is examined and found that such people experience high risk of low birth weight, respiratory disorders and annoyance from stench. All these studies, however, were not done from a green criminological perspective. Green criminology broadly includes the study by criminologists of environmental harms, environmental laws and environmental regulations. Academics in the field of criminology should, therefore, endeavour to study the environmental harms due to improper MSWM and also to study the laws and regulations relating to MSWM. Such a holistic approach would help understand specific environmental issues and outcome of such studies would also help the stakeholders concerned to ensure the right of citizens to adequate standard of living. As argued by several authors, green criminology is not an independent discipline or sub-discipline of criminology, rather it is a perspective to study any environment related issues. By including within its scope the issues such as impact of improper MSWM, green criminologists would contribute to a safe, just and environmentally sustainable community.

Taking forward the domain of green criminology may be one of the several ways to achieve the SDG 11. The right to adequate standard of living has been not only a subject of discussion in several national and international conferences, summits and 
other platforms for a very long time, it has been incorporated as one of the important SDG in the 2030 agenda. Expanding the scope of green criminology, thereby studying various environmental issues, would certainly enrich the existing literature. Also, the outcome of such intensive research from the green criminological perspective would form the knowledge base and would sensitise all the stakeholders.

\section{References}

A/CONF.48/14/Rev.1 Report of the United Nations Conference on the Human Environment. 5-16 June 1972.

A/RES/61/295 Declaration of the Rights of Indigenous Peoples. 2 October 2007.

A/RES/70/1 Transforming our world: the 2030 Agenda for Sustainable Development. 21 October 2015.

Adeola FO (2001) Environmental injustice and human rights abuse: The states, MNCs, and repression of minority groups in the world system. Hum Ecol Rev 8:39-59

Al Hussein ZR (2015) Introduction. Illustrated edition of the Universal Declaration of Human Rights. https://www.un.org/en/udhrbook/pdf/udhr_booklet_en_web.pdf. Accessed 20 Sep 2019

Almeida D, Berlin R, Allison K, et al (2003) Study Guide: The Right to Means for Adequate Health. University of Minnesota, Human Rights Library. http://hrlibrary.umn.edu/edumat/studyguides/righttohealth.html. Accessed 10 Aug 2019 Ammasi Krishnan M, Jawahar K, Perumal V, et al (2019) Effects of ambient air pollution on respiratory and eye illness in population living in Kodungaiyur, Chennai. Atmos Environ 203:166-171. https://doi.org/10.1016/j.atmosenv.2019.02.013

Bell S, McGillivray D, Pedersen O, et al (2017) Environmental Law. Oxford University Press, London

Bergersen O, Haarstad K (2014) Treating landfill gas hydrogen sulphide with mineral wool waste (MWW) and rod mill waste (RMW). Waste Manag 34:141-147. https://doi.org/10.1016/j.wasman.2013.09.012

Blaustein J, Pino NW, Fitz-Gibbon K, White R (2018) Criminology and the UN Sustainable Development Goals: The Need for Support and Critique. Br J Criminol 58:767-786. https://doi.org/10.1093/bjc/azx061 
Brickey KF (2008) Environmental Crime: Law, Policy, Prosecution. Aspen Publishers, New York

Brinkel J, Khan MH, Kraemer A (2009) A systematic review of arsenic exposure and its social and mental health effects with special reference to Bangladesh. Int J Environ Res Public Health 6:1609-1619. https://doi.org/10.3390/ijerph6051609

Bullard RD (2005) The Quest for Environmental Justice: Human Rights and the Politics of Pollution, 1st edn. Counterpoint, San Francisco

Central Pollution Control Board (2013) Status Report on Municipal Solid Waste Management. http://www.indiaenvironmentportal.org.in/files/file/MSW_Report.pdf. Accessed 10 Sep 2019

Chandra M (2015) Environmental Concerns in India: Problems and Solutions. J Int Bus Law 15:1-14.

Clifford M (1998) Environmental Crime: Enforcement, Policy, and Social Responsiblity, 1st edn. Aspen Publishers, Maryland

Deivanayagam C., Geeta R, Coelho K, et al (2007) Violations of environmental, labour $\&$ human rights due to garbage dumping \& burning at Kodungaiyur, Chennai. Community Environmental Moniotoring. http://www.sipcotcuddalore.com/downloads/Kodungaiyur_factfinding.pdf. Accessed 10 Sep 2019

E/CN.4/Sub.2/1994/9 Human Rights and the Environment. 6 July 1994

Emeseh E (2012) Human rights dimensions of contemporary environmental protection. In: Odello M, Cavandoli S (eds) Emerging Areas of Human Rights in the 21st Century: The Role of the Universal Declaration of Human Rights. Routledge, Oxon, pp 66-86 Eshanthini P, Padmini TK (2015) Impact of Leachate On Ground Water Quality Near Kodungaiyur Dumping Site, Chennai, Tamil Nadu, India. Int J PharmTech Res 8:171179

Etkin D (2016) Disaster Risk. Butterworth-Heinemann, Waltham

Fernández-Nava Y, Del Río J, Rodríguez-Iglesias J, et al (2014) Life cycle assessment of different municipal solid waste management options: A case study of Asturias (Spain). J Clean Prod 81:178-189. https://doi.org/10.1016/j.jclepro.2014.06.008 
Fyfe N, Reeves A (2010) The Thin Green Line? Police Perceptions of the Challenges of Policing Wildlife Crime in Scotland. In: Mawby RI (ed) Rural Policing and Policing the Rural: A Constable Countryside?, 1st edn. Routledge, London

GA/RES/217A (III) Universal Declaration of Human Rights. 10 December 1948.

GA/RES/2200A (XXI) International Covenant on Economic, Social and Cultural Rights. 16 December 1966.

Gouveia N, do Prado RR (2010) Health risks in areas close to urban solid waste landfill sites. Rev Saude Publica 44:859-866. https://doi.org/10.1590/S003489102010005000029

Greater Chennai. Corporation Soild Waste Management. http://www.chennaicorporation.gov.in/departments/solid-wastemanagement/index.htm. Accessed 6 Sep 2019

Greater Chennai Corporation (2017) Greater Chennai Corporation Disaster Management Plan 2017. http://www.chennaicorporation.gov.in/NorthMonSoon2017/cdmcb.pdf. Accessed 10 Sep 2019

Groombridge N (1998) Masculinities and Crimes Against the Environment. Theor Criminol 2:249-267. https://doi.org/10.1177/1362480698002002006

Hall M (2014) Environmental harm and environmental victims: Scoping out a "green victimology.” Int Rev Vict 20:129-143. https://doi.org/10.1177/0269758013508682 Joshi R, Ahmed S (2016) Status and challenges of municipal solid waste management in India: A review. Cogent Environ Sci 2:1-18. https://doi.org/10.1080/23311843.2016.1139434

Kaushal RK, Varghese GK, Chabukdhara M (2012) Municipal Solid Waste Management in India-Current State and Future Challenges: A Review. Int J Eng Sci Technol 4:14731489

Kumar S, Bhattacharyya JK, Vaidya AN, et al (2009) Assessment of the status of municipal solid waste management in metro cities, state capitals, class I cities, and class II towns in India: An insight. Waste Manag 29:883-895. https://doi.org/10.1016/j.wasman.2008.04.011 
Lillycrop KA, Costello PM, Teh AL, et al (2015) Association between perinatal methylation of the neuronal differentiation regulator HES1 and later childhood neurocognitive function and behaviour. Int J Epidemiol 44:1263-1276.

https://doi.org/10.1093/ije/dyv052

Lynch MJ (2012) Reflections on green criminology and its boundaries. In: South N, Brisman A (eds) Routledge International Handbook of Green Criminology. Routledge, Oxon

Lynch MJ (1990) The Greening of Criminology: A Perspective for the 1990s. Crit Criminol 2:11-12

Lynch MJ, Stretesky PB (2003) The Meaning of Green: Contrasting Criminological Perspectives. Theor Criminol 7:217-238.

https://doi.org/10.1177/1362480603007002414

Lynch MJ, Stretesky PB (2014) Exploring Green Criminology: Toward a Green Criminological Revolution. Aspen Publishing Limited, Surrey

Lynch MJ, Stretesky PB, Long MA (2015) Environmental justice: A criminological perspective. Environ Res Lett 10:. https://doi.org/10.1088/1748-9326/10/8/085008

Massari M, Monzini P (2004) Dirty Businesses in Italy: A Case-study of Illegal Trafficking in Hazardous Waste. Glob Crime 6:285-304.

https://doi.org/10.1080/17440570500273416

Mehta MC (2009) In the Public Interest: Landmark Judgement and Orders of the Supreme Court of India on Environment and Human Rights. Prakriti Publications, New Delhi

National Informatics Centre Chennai District Profile. https:/chennai.nic.in/aboutdistrict/district-profile/. Accessed 6 Sep 2019

Nurse A (2017) Green criminology: Shining a critical lens on environmental harm comment. Palgrave Commun 3:1-3. https://doi.org/10.1057/s41599-017-0007-2

O'Connor Shelley T, Crow MS (2009) The nature and extent of conservation policing: Law enforcement generalists or conservation specialists? Am J Crim Justice 34:9-27. https://doi.org/10.1007/s12103-008-9057-8 
O’Gara R, Mollo M, Wagner JM, et al (2007) Environmental rights Report 2007. Oakland

Office of the Registrar General \& Census Commissioner 2011 Census Data. Office of the Registrar General \& Census Commissioner, Ministry of Home Affairs, Government of India. http://www.censusindia.gov.in/pca/SearchDetails.aspx?Id=720012. Accessed 6 Sep 2019

Parameswari K, Mudgal B V. (2014) Geochemical investigation of groundwater contamination in Perungudi dumpsite, South India. Arab J Geosci 7:1363-1371. https://doi.org/10.1007/s12517-013-0832-6

Patil BS, Agnes Anto C, Singh DN (2017) Simulation of municipal solid waste degradation in aerobic and anaerobic bioreactor landfills. Waste Manag Res 35:301312. https://doi.org/10.1177/0734242X16679258

Pearce F, Tombs S (2019) Toxic Capitalism: Corporate Crime and the Chemical Industry, 1st edn. Routledge, London

Pellow DN (2007) Resisting Global Toxics: Transnational Movements for Environmental Justice. MIT Press, Cambridge

Pujara Y, Pathak P, Sharma A, Govani J (2019) Review on Indian Municipal Solid Waste Management practices for reduction of environmental impacts to achieve sustainable development goals. J Environ Manage 248:1-14.

https://doi.org/10.1016/j.jenvman.2019.07.009

Ruggiero V (1996) Organized and Corporate Crime in Europe: Offers That Can’t Be Refused. Dartmouth Publishing Co Limited, Hampshire, UK

Shaddick G, Ranzi A, Thomas ML, et al (2018) Towards an assessment of the health impact of industrially contaminated sites: Waste landfills in Europe. Epidemiol Prev 42:69-75. https://doi.org/10.19191/EP18.5-6.S1.P069.089

Sharholy M, Ahmad K, Mahmood G, Trivedi RC (2008) Municipal solid waste management in Indian cities - A review. Waste Manag 28:459-467.

https://doi.org/10.1016/j.wasman.2007.02.008

Singhal S, Pandey S (2001) Solid waste management in India: Status and future directions. TERI Inf Monit Environ Sci 6:1-4 
Situ Y, Emmons D (2000) Environmental Crime: The Criminal Justice System's Role in Protecting the Environment. SAGE Publications, Inc., California

South N (1998) A Green Field for Criminology? Theor Criminol 2:211-233.

https://doi.org/10.1177/1362480698002002004

United Nations The universal declaration of human rights.

https://www.un.org/en/universal-declaration-human-rights/index.html. Accessed 13 Oct 2019

United Nations (2015) Illustrated edition of the Universal Declaration of Human Rights. https://www.un.org/en/udhrbook/pdf/udhr_booklet_en_web.pdf. Accessed 13 Oct 2019

United Nations (2019) The sustainable development goals report 2019. 44-45. https://unstats.un.org/sdgs/report/2019/The-Sustainable-Development-Goals-Report2019.pdf. Accessed 13 Oct 2019

United Nations Economic Commission for Europe (1998) Convention on Access to Information, Public Participation in Decision-Making and Access to Justice in Environmental Matters.

https://www.unece.org/fileadmin/DAM/env/pp/documents/cep43e.pdf. Accessed 13 Oct 2019

Vrijheid M (2000) Health effects of residence near hazardous waste landfill sites: A review of epidemiologic literature. Environ Health Perspect 108:101-112

White R (2003) Environmental Issues and the Criminological Imagination. Theor Criminol 7:483-506. https://doi.org/10.1177/13624806030074005

White R (2008) Crimes against Nature: Environmental Criminology and Ecological Justice. Willan Publishing, Devon, UK

White R (2013) The Conceptual Contours of Green Criminology. In: Walters R, Westerhuis DS, Wyatt T (eds) Emerging Issues in Green Criminology: Exploring Power, Justice and Harm. Palgrave Macmillan, London, pp 17-33

World Health Organization (2016) Waste and human health: Evidence and needs. http://www.euro.who.int/_data/assets/pdf_file/0003/317226/Waste-human-healthEvidence-needs-mtg-report.pdf. Accessed 10 Sep 2019 
Ziraba AK, Haregu TN, Mberu B (2016) A review and framework for understanding the potential impact of poor solid waste management on health in developing countries. Arch Public Heal 74:1-11. https://doi.org/10.1186/s13690-016-0166-4 